\title{
Educational videos: After the why, the how
}

\author{
Manuel Rajadell(D), Federico Garriga-Garzón(iD \\ Universitat Politècnica de Catalunya (Spain) \\ manuel.rajadell@upc.edu,federico.garriga@upc.edu
}

Received March, 2017

Accepted October, 2017

\section{Abstract}

Purpose: The introduction of educational videos into university education is an indisputable reality. Numerous scientific publications have outlined the advantages to students: flexibility, motivation, encouraging self-learning, lower costs, etc. The aim of this paper is to explore the steps required to make educational videos and highlight the need for educational institutions to provide teachers with the means to enable them to improve the quality of their multimedia material productions. Policies in this direction would help to improve the training of future professionals and enhance the opportunities offered by podcasts.

Design/methodology: A literature review and a survey have been conducted. Starting in the first semester of the academic year 2012-2013, a questionnaire has been applied systematically to students and the corresponding population parameters estimated with a $95 \%$ confidence level.

Findings: Students consider educational videos as supplementary material which complement traditional methodologies and favour self-learning as well as offering flexibility at no additional cost. Teachers can produce their own high-quality multimedia material, which in turn requires a consistent evolutionary process in elaborating within the changing possibilities that information technologies offer. 
Originality/value: This work deals with the treatment of technical issues and based on our studies suggests the process to be followed by teachers when making educational videos. References to this subject in the literature were found to be somewhat limited.

Keywords: Podcasting and education, Educational videos, Video in the learning process

Jel Codes: A2

\section{Introduction}

The process of transferring information, whatever the content, has been changing due to the convergence of three sectors: information technology, media and telecommunications. The users have also changed and their desire for autonomy is growing as they choose what type of information they are interested in and where to access it (Nagy \& Bernschütz, 2015). Currently information, unlike other economic resources, is not scarce and in fact especially via the Internet it is abundant and to some extent excessive. University teaching and especially that oriented to the understanding of industrial organization is not immune to this phenomenon. Therefore, the way to teach a class has changed, or should have, with models incorporating the new types of resources available. This change can be explained by the dynamic development of methods and tools in information technology. At the same time, this development not only triggers flexible learning methods but also supports them through the creation of a new type of knowledge transfer (Allen \& Seaman, 2012) and video is a good example of this. In this paper the term video refers to media files that are distributed through a digital format over the Internet using personal computers or mobile devices (McGarr, 2009).

The increase in the wealth of audiovisual media presents interesting possibilities that allow for teaching while economising attention. This work is underlain by the Principle of Attention Economy (Davenport \& Beck, 2001; Goldhaber, 1997; Simon, 1971) according to which, the more information there is, the lower the attention span and time available to assimilate it. If this concept is transferred to teaching, the teacher is increasingly becoming a mere manager of knowledge who should strive to focus students' attention. In general, interest and attention in knowledge presented in master classes is progressively being lost as new technologies allow students to obtain such knowledge by other means and capture their attention (Rué, 2009). The objective is an improvement in performance through self- 
learning training and an increase in its effectiveness and flexibility within the framework of a society that organizes itself on the net through a process of both technical and cultural transformation (Castells, 2003).

On the other hand, the tendency towards a reduction in hours devoted to master classes or lectures requires the application of new technologies in order to introduce flexibility in teaching (McGarr, 2009), with greater emphasis made on learning activities than on teaching, not forgetting the overall development of the human being contemplating both ethics and personal development (Fernández, Fernández \& Ortiz, 2003). Reducing class sessions favors the introduction of video distributed from streaming video channels through a data stream over the Internet, direct playback on a web page in real time without having to first download the file to your computer (Shephard, 2003).

This article describes the production process of multimedia assemblies whose aim is to harness the potential of audiovisual language and increase class attention and efficiency by reducing the zapping effect in which a high percentage of students who attend class are immersed. Given that the current trend is to emphasize learning rather than learning tasks, the videos point in this direction.

\section{Educational videos}

Videos began to enter teaching in the 20th century during the 1980s. Rapid advances in communication and information technology have made them a resource with unlimited possibilities (Nagy \& Bernschütz, 2015; Pink, 2007) accessible to non-professional users (Shrun, Duque \& Brown, 2005). With the development of computer technology, the possibility to create, edit and share videos has increased the use of videos in university teaching as outlined by Kay and Kletskin (2012).

Many researchers have recognized the usefulness of video in the learning process, emphasizing its effectiveness as a training tool. Cabero (2007) summarizes the possibilities of videos accentuating the high number of alternatives to visualise them and their adaptation to any educational level, as well as pointing out their limitations such as favoring passive attitudes. With the evolution of digital technology and fast access streaming video channels via the Internet, video has moved from being an important element to being considered as teaching methodology, with the increase in the number of settings which use dynamic image as a captivating element for students' attention (Simó et al., 2009), to the point that some authors (Choi \& Johnson, 2007; Shyu, 2000; Wisher \& Curnow, 1999) argue that it is much more efficient than other methodologies based on books or text material. Hallett and Fari a's 
study (2006) concludes that multimedia material that integrates audio, video, animations, graphics and text enables greater content memorization than traditional Power Point slides.

It should be noted that it is proposed that videos are used as complementary components classroom sessions. Some studies have shown that when used as a complement, positive results are obtained in student performance (Dupuis, Coutu \& Laneuville, 2013; Traphagan, Kusera \& Kishi, 2010; Wieling \& Hofman, 2010; Williams, Birch \& Hancock, 2012), whereas when used simply to replace class sessions there is not the same improvement in learning outcomes (Giannakos \& Vlamos, 2013; McKinney, Dyck \& Luber, 2008).

According to Caspi, Goirsky and Privman (2005), educational videos can be divided into three categories depending on their use and purpose: demonstration videos, narrative videos and videos of keynote lecture sessions. This paper belongs to the first category characterized by offering a learning tool to further autonomous learning. Also, video is a motivating tool for learning (Fisher \& Baird, 2006; Marx \& Frost, 1998), which could be justified by the power of attraction of audiovisual language and its influence on emotions which can serve to reinforce other less attractive activities. This motivation should result in an increase in the number of hours spent on various subjects, through viewing multimedia content and using the opportunity to combine this with other resources such as text, graphics, debates, etc. This phenomenon is described by the Premack principle coined by the American psychologist David Premack whereby when two stimuli are linked together, the one that is most likely to occur positively reinforces the one that is least likely to occur.

The potential of digital technologies help teaching innovation and autonomous learning (Steffens, 2001) as it is evident that students are very used to this type of technologies which enable good quality visualization in different media and devices: computers, tablets, smartphones, iPods, etc., and are even exchangeable via bluetooth. In this way students are ensured access to quality, low cost material and as often as they wish (Foertsch, Moses, Strikwerda \& Litzkow, 2002; Shantikumar, 2010; Winterbottom, 2007) from anywhere and via multiple platforms, which is a very interesting possibility in the context of autonomous learning (Bolliger, Supanokorn \& Boggs, 2010; Shantikumar, 2010; Simó et al., 2009). This flexibility enables methodologies to be combined in a critical manner in order to develop a sea-change transformation in students (Aiello \& Willem, 2004). In this regard Dr.Dilleman of the Leuven Catholic University proposes that education should be presented as on a menu, just as in a baute cuisine restaurant: an easy menu to read (friendly interface), offering nouveau cuisine (modular and free choice) open 24 hours (distance learning) and first class food and service (tutoring and student control). 
According to Peters (1998), autonomous learning not only provides students with the opportunity to develop their initiatives and plan their training process, but forces them to do so. In fact they can decide where, when, how long and how fast to study, which makes them assume a higher level of responsibility. At this point we cannot avoid mentioning some practical factors such as the possibility of enabling the monitoring of different subjects available which have complicated timetables (Foertsch et al., 2002) and saving some trips to attend class (Mckinney \& Page, 2009). For a review of how autonomous learning is considered enhanced in different learning environments by technologies we recommend texts by Steffens (2006).

\section{Steps to be taken to in the development of educational videos}

Once interest in the production of multimedia material has been justified the next step is to present research work carried out in order to answer a fundamental question: How to tackle the challenge of making educational videos. Initially, for the use of multimedia material in classes we propose to follow an evolutionary process consisting of five phases (Rajadell \& Garriga, 2013):

- For decades that has been possible to introduce audiovisual elements in teaching through the recommendation of movies to students. Also, TV shows or documentaries can be introduced by the teacher in the teaching and learning process (Fourcade, 2008).

- The selection of a set of sequences from Internet to divulge a topic or certain concept. These sequences can be selected according to user requirements (Zhang, Zhou, Briggs \& Nunamaker, 2006). This easy and affordable option from the huge range available on youtube enables the teacher to bring interesting materials from the net, generate debate and provide examples. There is also the possibility of adding subtitles to this material using a free, multiplatform, manual and very precise tool such as Aegisub.

- Make low-cost video screencasts which consist of a digital recording to the computer screen and includes an audio commentary. This simply takes advantage of the ease of using Microsoft Producer for PowerPoint, Screencast-O-matic or Camtasia Studio which all easily enable screenshot capture from a computer screen as well as Adobe Captivate. You can also take pictures with a webcam or another video camera and attach an audio file. This format is easily edited using tools suitable for beginners such as MovieMaker for Windows or iMovie for Mac, which as well as being easier to use are also free. Editing lets you add text which in turn helps to 
highlight the structure and main concepts. The results obtained provide high educational value and can be presented in different final resolution formats to enable access for all students (Winterbottom, 2007). The files are shared as podcasts. While the term podcast initially referred to audio recordings today it applies to a distribution method via Internet of any digital file or collection of files, to be played back on portable devices such as personal computers, iPods, smart-phones or tablets (Lazzari, 2009) for an audience that wants to play back on demand.

- Make a montage using video clips. Internet is an inexhaustible source of images and sound resources, although only those that are free of copyright can be used. CreativeCommons licenses allow you to use material created by others. After acquiring some knowledge it is possible to work with Sony Vegas, Adobe Premiere or Final Cut to edit video clips using material compiled from various sources, attach titles and add one or more audio tracks in order to create an enjoyable and effective presentation.

- Create your own multimedia montage production. This is undoubtedly the most complicated and costly. It stems from an idea that answers specific training needs and establishes a script organizing information sequentially. The visual style is then decided before passing to the recording phase taking care of both sound and image, requiring the rehearsal of speech several times. In the editing phase poor scenes are removed, the length of the sequences is managed and special effects, titles, subtitles, transitions, music and narration are added. The process ends with the publication of the video on a digital platform or on a video streaming channel on the Internet.

We should note that there are tools to create lists of questions in order to gather information and validate the knowledge acquired by students, so that videos become interactive. One of these tools is Edpuzzle that as well as providing teachers with links to course materials and introducing video questionnaires also provides feedback on each possible answer. An alternative, with similar characteristics, is Educanon.

Teachers should undertake the evolutionary process described above in order to reach the last level, that is, creating original multimedia productions, and be aware that with proper design it is possible to provide tools to facilitate knowledge which does not have to be to the detriment of the role they serve as trainers but rather the contrary. Through a combined use of classroom teaching and learning objects such as multimedia materials, teachers reserve themselves for the most substantial part of the training activity, which is to provide approaches and guidelines that need greater communication and empathy. 
The teacher should concentrate on what students cannot do for themselves and from this approach some really relevant teaching competences emerge in relation to the activity of teaching (Rué, 2009).

We should also note that audiovisual resources are not intended to eliminate teachers (McKinney et al., 2008) but rather intend to integrate into the educational system, given that multimedia montages allow the use of real life cases to show examples of both good and bad practices or real-world illustrations (Jarvis \& Dickie, 2009), summarize a class lesson or chapter of the textbook (McGarr, 2009), visualize an experiment before doing it, pose a problem or a video conundrum (Bartolomé, 2008), establish a starting point for a debate or a class (Bennett \& Glover 2008; Foertsch et al., 2002), present a method, algorithm or way of working, intuitively present an idea, solve a problem graphically (Kay, 2012), create stories, visual metaphors, etc.

Podcasts enable students to have higher quality notes (McKinney et al., 2008; Traphagan et al., 2010), and they also offer the option to correct them (Cramer, Collins, Snider \& Fawcett, 2007; Evans, 2008). Fourcade (2008), states that these possibilities not only serve to motivate but also create participatory dynamics and develop expressive and perceptual abilities. Podcasting has made distance education more accessible to a wide diversity of students (Cebeci \& Tekdal, 2006), proving effective in reducing isolation and anxiety in students as it promotes a sense of belonging to a community (Lee \& Chan, 2007), and also tightens the relationship between students and teachers (Fernández, Simó \& Sallán, 2009). In the case of foreign students podcasts help them overcome language difficulties in the first months of course due to the ease with which they can replay them (Evans, 2008).

Notably video is economically profitable in reducing costs by allowing reuse (Jung, 2005) and in postgraduate training it decreases the number of class-based sessions. However, if all media are bidirectional, video is no exception, so in order to maximize its broadcast capability it is not enough to access the tools or heavily use the media but it is also necessary to master the language (Salinas, 2012). The creative ability to communicate also gives students the possibility to critically receive messages from the media, which is to say that video is a useful resource both in terms of means and content.

\section{How to make educational videos}

Video production through your own material preparation can be done in a number of ways, always based on the videographic language that has emerged from the effort to develop audiovisual messages through the use of existing technical means of collection and reproduction. Although Ractham and 
Zhang (2006) suggest that podcast production is simple for teachers, they will still have to face, when producing a video, an obvious lack of training in carrying out such a project with a guarantee of success and acceptable technical parameters: image quality, format explanations, cognitive load, tone of voice, rhythm, length and scene segmentation, etc. In accordance with Kay (2012), despite the importance of the technical characteristics of videos and its effect on learning, there are no studies to evaluate this relationship.

The point is that if the widespread use of podcasting in education is a reality, practical concerns about their production have to be properly addressed and this implies an improvement in the level of institutional support as stated in research by Lonn and Teasley (2009). Our study suggests that there has been very little research done which deals with the fundamental issues about the content and authoring of podcasts in order stimulate a more innovative use of this technology. It rarely seems to be considered for research or investigation. In our environment the development of this type of material depends only on teachers' vocation for education as they do not receive any encouragement to do so and if they spend an excessive amount of time cannot then deal with the activities of their own research which can end up penalizing them.

Ellis and Cohen (2001) published research which warned that although podcasts can be useful, attractive and received with great enthusiasm by students, their use should be weighed up against the cost of their production. Also, Brown and Green (2007) claim that producing a video is a difficult task for most teachers. This is possibly still valid today although production costs are gradually getting lower.

The teacher's work should focus on the development of the script, which is the result of a creative effort. All too often this is left in the hands of the director who ends up materializing the project and who finally transforms it into a new project. For the director the technical script is an obligatory work reference, outlining which must be achieved. In this sense the script is a starting point as well as a point of arrival (Fernández and Martínez, 2007).

In our case, the scripts were created by including all the images and expressions of those concepts likely to be disclosed. At the time of preparing the scripts the following points should be decided upon:

- What to explain. Define the thematic focus to be addressed and the ideas you want to communicate and then proceed to summarize (avoiding unnecessary terms or words) and finally organize the text. As in the cinema a script should be developed to present ideas and should be the basis for the final product to explain the target content with the necessary clarity. 
The script requires an effort in documenting rationally, aesthetically and scientifically, in order to then select the essentials.

- How the videos will be used. The video concept of a television presenter, where the teacher is in front of a blackboard or sitting in a seat, is rejected. The video must not turn into a talking head. The unspoken rule about visual storytelling is that a gesture is preferable to dialogue. It is advisable to look at videos which are similar examples to the proposed project and read articles in magazines so as to exploit the unique properties of video (sound interface and image), which invites you to create things differently than normally (Rea \& Irving, 2002).

- How long. The benefits and challenges posed by the introduction of video in teaching is closely related to their length (Kay, 2012), a two-minute video of has a different impact than a tenminute one. The attention span is a scarce resource in developed societies where some groups offer time and others demand it, so we should take into account the law of supply and demand when communicating with others (Núñez, 2007). Since the time of uninterrupted attention lasts about ten minutes (Weinschenk, 2012), the videos that we have made are designed not to ever exceed this time which has been set as a maximum. This feature makes them really manageable via Internet and can easily be downloaded and played on any multimedia device.

Through adapting the written script a technical one is produced which contains the specific and necessary indications for an effective production. The script is, for the producer, equivalent to a blueprint for a project in building construction (Rea \& Irving, 2002). The script dictates what needs to be done in the same way that the building plans indicate where to place the bricks.

The descriptive language of the written script requires a translation into concrete audiovisual technical solutions which will be found in the technical script. This code change can only be carried out by the person who masters audiovisual language, its innate rules and who also knows the technical possibilities. It is certainly work to be done by an expert who masters the media and all its complexity (Fernández \& Martínez, 2007), and for this reason requires the help of an expert in audiovisual communication to take responsibility that the final product reflects all those indications considered necessary at the time of its production and assembly (editing, soundtrack and post-production process).

In our case, the initial text was segmented into sequences to facilitate the monitoring of video production. By way of example Table 1 shows the written script developed for the first sequence of one of the videos. The two-column format is commonly used in audiovisual documentary types, in one column the sound is given and in the other the visual image. The first column refers to the sequence 
number, the second column gives the text that will become the audio in the video while the third indicates what should be displayed on the screen.

\begin{tabular}{|c|l|l|}
\hline $\mathbf{N}^{\mathbf{o}}$ & Written script & Technical script \\
\hline 1 & $\begin{array}{l}\text { The analysis of economic and financial } \\
\text { information is a basic tool in any decision }\end{array}$ \\
$\begin{array}{l}\text { process which is why it is relevant to managers, } \\
\text { owners, advisors, and creditors, among others. }\end{array}$ & $\begin{array}{l}\text { Keywords: Company, money, business people } \\
\text { (shareholders, managers, advisors, creditors, etc.) }\end{array}$ \\
$\begin{array}{l}\text { This video shows how to perform the analysis of } \\
\text { economic and financial information on a balance } \\
\text { sheet and the accounts statement of a company. }\end{array}$ & $\begin{array}{l}\text { Show the balance sheet and accounts statement } \\
\text { which are based on the financial information. }\end{array}$ \\
\hline
\end{tabular}

Table 1. Example script

In the editing stage scenes are selected and the final length is determined, titles are added as well as the soundtrack. The link between auditory and visual information provides the student with a multisensory experience (Hampton, 2002), improving their motivation more effectively than written text (Choi \& Johnson, 2007; Shyu, 2000). The inclusion of music, which can be created using free or professional software, is entirely intentional in order to release dopamine when listening which acts as a neurotransmitter in the central nervous system creating a pleasant feeling and a good mood (Salimpoor. Benevoy, Larcher, Dagher \& Zatorre, 2011), ideal to facilitate learning.

In our case, the end result is a set of videos that have been published on a digital Moodle type platform with free access for students. This platform is a web application that allows the integration of a large number and variety of online multimedia resources thanks to its design structure and the database it uses. The insertion of the videos is a simple task that does not require the use of resources such as forums or websites.

\section{Results}

Since the first semester of 2012-2013 a questionnaire has been used with the aim of getting the corresponding feedback in relation to the value added through the use of videos in the learning process. Considering the objectives and the exploratory nature of the work a survey based on closed questions was developed with to the aim of knowing students opinions. In addition, more specific objectives were included: 
- To determine whether the use of video as a teaching tool favors learning or not.

- To know the students' assessment of the proposed content: presentation clarity and level of difficulty.

- To know the degree of student satisfaction regarding the content and technical quality of the multimedia material made available.

The anonymous surveys were conducted by teachers at the beginning of the last class session of the course, which may introduce some bias as students who attend class regularly have higher motivation and are more interested in the skills and educational activities carried out the teacher (Fjortoft, 2005). It is worth noting there is research based only on paper to analyze the use of videos in teaching while others, based on the mixed use of paper and online versions (Chester, Buntine, Hammond \& Atkinson, 2011). The questionnaire was conducted based on two major ambits:

- Ambit 1 (questions 1 through 6 of the questionnaire). Rate the content, its level of depth and informative clarity.

- Ambit 2 (questions 7 to 14 of the questionnaire). Rate the videos as a learning tool, both from the perspective of their technical function and their contribution to the training process.

On concluding the period of research, of the 578 students enrolled 264 responses were obtained. The questionnaire includes fourteen items to make it a quick survey, using an ordinal scale such as the Likert scale, for its ease, low cost, and mainly because it intends to measure individual attitudes. Summers (1982) defines attitude as the sum total of inclinations and feelings, prejudices or distortions, preconceived notions, ideas, fears, threats and convictions of an individual about any specific issue, and attitude is expressed through opinions (Ávila, 2006).

The scale has been designed according to a series of items that reflect a positive or negative opinion about a question, each divided into five alternatives: (5) strongly agree, (4) agree, (3) indifferent (2) disagree and (1) strongly disagree. These items have been drafted with criteria proposed by Weiers (1986): less than twenty words, logical, simple and not compound sentences, avoiding the words: everyone, always and nobody. Besides, an attempt has been made to avoid acquiescence (agreement with any assertion) by introducing a negative item. To corroborate the content validity, consultation was undertaken with a number of teachers in the department and some from other areas of knowledge who use educational videos. The results obtained are shown in Table 2. 


\begin{tabular}{|c|c|c|c|c|c|c|}
\hline $\mathbf{N}^{\mathbf{o}}$ & Question & 5 & 4 & 3 & 2 & 1 \\
\hline 1 & They have helped me to have a clearer view of the subject & 3 & 55 & 154 & 41 & 1 \\
\hline 2 & They increased my expectations about the subject & 12 & 93 & 79 & 67 & 13 \\
\hline 3 & They have only been supplementary & 14 & 89 & 92 & 42 & 27 \\
\hline 4 & They have led me to not give importance to other media & 0 & 13 & 26 & 106 & 119 \\
\hline 5 & I prefer the videos to PDF files & 0 & 40 & 119 & 79 & 26 \\
\hline 6 & The technical quality of a teaching video is fundamentally important & 120 & 95 & 46 & 2 & 1 \\
\hline 7 & They have been relevant to my learning & 18 & 90 & 142 & 14 & 0 \\
\hline 8 & They have been motivating for my learning & 0 & 132 & 119 & 11 & 2 \\
\hline 9 & They have helped me to discover things about the subject & 26 & 53 & 132 & 53 & 0 \\
\hline 10 & They have helped me in a different way than the class notes & 15 & 52 & 158 & 0 & 39 \\
\hline 11 & They are a more harmful than positive tool & 0 & 14 & 39 & 53 & 158 \\
\hline 12 & They have improved our collaborative work & 0 & 53 & 91 & 79 & 41 \\
\hline 13 & They have allowed me to learn in a different way & 26 & 133 & 66 & 26 & 13 \\
\hline 14 & Their quality can be as important as their content & 110 & 115 & 18 & 15 & \\
\hline
\end{tabular}

Table 2. Results obtained from the student survey

Below, the values obtained from the statistics of central tendency and dispersion (Table 3) are shown.

\begin{tabular}{|c|c|c|c|c|}
\hline $\mathbf{N}^{\mathbf{0}}$ & Question & Mean & SDeviation & Mode \\
\hline 1 & They have helped me to have a clearer view of the subject & 3.1 & \pm 0.75 & 3 \\
\hline 2 & They increased my expectations about the subject & 3.1 & \pm 0.99 & 4 \\
\hline 3 & They have only been supplementary & 3.1 & \pm 1.06 & 3 \\
\hline 4 & They have led me to not give importance to other media & 1.7 & \pm 0.83 & 1 \\
\hline 5 & I prefer the videos to PDF files & 2.7 & \pm 0.85 & 3 \\
\hline 6 & The technical quality of a teaching video is fundamentally important & 4.3 & \pm 0.79 & 5 \\
\hline 7 & They have been relevant to my learning & 3.4 & \pm 0.70 & 3 \\
\hline 8 & They have been motivating for my learning & 3.4 & \pm 0.61 & 4 \\
\hline 9 & They have helped me to discover things about the subject & 3.2 & \pm 0.87 & 3 \\
\hline 10 & They have helped me in a different way than the class notes & 3.0 & \pm 1.01 & 3 \\
\hline 11 & They are a more harmful than positive tool & 1.7 & \pm 0.92 & 1 \\
\hline 12 & They have improved our collaborative work & 2.6 & \pm 0.98 & 3 \\
\hline 13 & They have allowed me to learn in a different way & 3.5 & \pm 0.97 & 4 \\
\hline 14 & Their quality can be as important as their content & 4.2 & \pm 0.94 & 4 \\
\hline
\end{tabular}

Table 3. Statistical results

The results show the extent to which students feel that the videos are appropriate to their training needs. They show an overall student satisfaction for their production and positive perceptions in relation to the impact on their learning. This is possibly due to the connection with current culture, transmitting content accessible from technological tools used every day.

The sample has not taken into account student profile, which implies a limitation of the study given the existence of at least two types of students: idealists and pragmatists. The idealists enjoy traditional type conferences while the pragmatists simply look for enough information to pass, so for the latter group videos fit well with their profile (Dolnicar, 2005). Another issue which is not analyzed is the influence 
of age on the perception of satisfaction about using teaching videos. In our case this had little effect as the students in the study are mostly aged between twenty and twenty-eight.

The answer to the question of whether the videos have helped to discover new things is conditioned by the fact that they follow the pedagogical strategy of presenting information and therefore do not require an active attitude on behalf of the students. It might be worth considering the strategy of involving students in creating their own videos, because they learn through working, collaborating and possibly developing academic videos. With this approach the perception students expressed that the videos contributed little to collaborative work videos could be improved.

With regard to the opinion of whether the videos have helped in a different way than traditional notes, the results obtained strengthen McKinney and Page's (2009) theory as they back the new learning opportunities provided and contradict the results presented by Hew (2009) because students do not declare that they use them to retrieve or clarify any doubts generated in class. However, Hew's (2009) work only analyzed eleven items and they were mostly descriptive studies.

Most students say the videos help them to have a clearer view, or that they have only been a new addition to the subject or that have helped in a different way than notes. Lonn and Teasley's (2009) results lead in the same direction stating that podcasts constitute complementary or refresher material when preparing for evaluations. This all shows that for podcasts to be truly beneficial students have to keep doing the same things they always have, which is fully consistent with the findings of research by McKinney et al. (2008).

Quality is a fundamental attribute in the same way that the content is, so you need to allocate resources to technical aspects. However, possibly in any educational institution, there is limited teacher involvement in the development of digital educational content. According to Martínez and GarcíaBeltrán (2003), the reasons for this are that, on the one hand, teachers are not usually an experts in content generation computer tools, and on the other hand, these developments represent more work without any financial or professional incentive.

It's worth mentioning that if podcasts help students as we have upheld, it is not so clear if podcasting contributes to the improvement in the quality of education as a number of teachers simply limit their contribution to capturing, displaying and transmitting content without modifying the teaching method in class (Lonn \& Teasley, 2009), although there are studies which position themselves against this affirmation (Campbell, 2005; Cebeci \& Tekdal, 2006). If teachers do not find a way to change their teaching methodology by using different forms of podcasting, students perceive this as just another 
educational resource and teachers will not succeed in the introduction of innovative and interactive activities to their lectures.

The survey results support the conclusion that the videos produced are welcome, there is an increase in student satisfaction rates and that they are considered useful for training, in line with other studies (Dupuis et al, 2013;. Evans, 2008; Kay, 2012; Nagy \& Bernschütz, 2015; Williams et al, 2012). In addition, the characteristics of flexibility, ease of access and cost are valued, so there should be diversification and expansion to the supply of content. The results obtained do not establish that videos will allow increasing educational independence away from textbooks or teachers, which coincides with the view of Salinas (2012), nor has there been detected a decline in class attendance which is also consistent with studies of Evans (2008), Kay (2012) and Lonn and Teasley (2009). It is also not possible to conclude from the study that the use of educational videos helps to improve students' marks in exams, in agreement with work by Chester et al. (2011) and Foertsch et al. (2002).

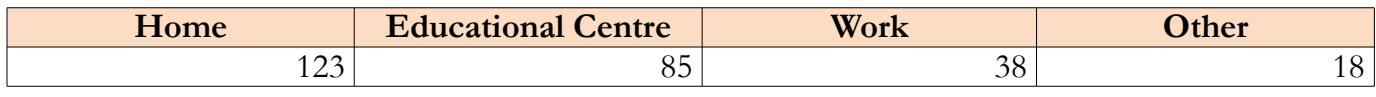

Table 4. Results in terms of place of use

Control over the place of learning provided by videos has been discussed in the literature in numerous works (Chester et al, 2011; Hill \& Nelson, 2011; Winterbottom, 2007). The re sults obtained (Table 4) reveal the flexibility provided by multimedia material as it can be used mainly at home (46.6\%), educational centers (32.2\%), work (14.4) and elsewhere such as on journeys by public transport (6.8\%). With this data we can conclude that $67.8 \%$ of students access outside the educational institution. Students mostly watch the multimedia material in classical learning situations, as only a minority (18\%) make the most of other times.

\section{Conclusions}

This paper has reached its proposed objective of establishing the necessary steps to produce educational videos and has highlighted the need for educational institutions to devote resources to further improving the quality of multimedia material which teachers can produce. Also, it can be seen that with podcasts students have material which perfectly complements class notes, and the declining use of textbooks and PowerPoint presentations. The results of the survey highlight the need to 
diversify and expand the range of content. However, for greater integration of the videos in the university lectures rooms it would be advisable to increase teachers' motivation through the use of some professional incentives or recognition. Consideration should also be given to training teachers to produce multimedia content enabling them to fulfill the required technical quality.

Finally, it should be noted that it is not the instrument which improves teaching, but rather the way, the predisposition and topics presented by the teacher, not forgetting that improvement in teaching starts with the resolve and interest of teachers. As stated by the famous biologist Edward Wilson (2007) passion is the engine of knowledge, the teacher's commitment is much more effective if it is expressed both in the art of teaching and personal love for the subject... students need find tutors in whom to trust, heroes to emulate and tangible and lasting success. Teachers with this profile feel in their element (Robinson \& Aronica, 2011) and in relation to the development of educational video s, their goal will go beyond the educational objectives and achieve the status of art.

\section{References}

Aiello, M., \& Willem, C. (2004). El blendedlearning como práctica transformadora. Pixel-BitRevista de Medios y Educación, 23, 21-26.

Allen, I.E., \& Seaman, J. (2012). Changing course: Ten years of tracking online education in the United States. London: Babson Survey Research Group and Quahog Research Group, LLC. Pearson Foundation.

Ávila, H.L. (2006). Introducción a la metodología de la investigación. México: Instituto Tecnológico. Cd. Cuauhtémoc, Chihuahua.

Bartolomé, A. (2008). Entornos de aprendizaje mixto en educación superior. Revista Iberoamericana de Educación a Distancia, 11(1), 15-51.

Bennett, P., \& Glover, P. (2008). Video streaming: Implementation and evaluation in an undergraduate nursing program. Nurse Education Today, 28(2), 253-258. https://doi.org/10.1016/j.nedt.2007.04.005

Bolliger, D.U., Supanokorn, S., \& Boggs, C. (2010). Impact of podcasting on student motivation in the online learning environment. Computers \& Education, 55(2), 714-722.

https://doi.org/10.1016/j.compedu.2010.03.004

Brown, A., \& Green, T.D. (2007). Video podcasting inperspective: the history, technology, aesthetics, and instructional uses of a new medium. Journal of Educational Technology Systems, 36(1), 3-17. 
Cabero, J. (2007). El vídeo en la enseñanza y formación. Nuevas Tecnologías aplicadas a la educación. Madrid: McGraw-Hill.

Campbell, G. (2005). There's something in the air: Podcasting in education. Educause Review, 40(6), $32-46$.

Caspi, A., Gorsky, P., \& Privman, M. (2005). Viewing comprehension: Students' learning preferences and strategies when studing from video. Instructional Science, 33(1), 31-47. https://doi.org/10.1007/s11251004-2576-x

Castells, M. (2003). La era de la información. Tomo I: La sociedad red. Barcelona: Alianza Editorial.

Cebeci, Z., \& Tekdal, M. (2006). Using podcasts audio learning objects. Interdisciplinary Journal of Knowledge and Learning Objects, 2, 47-57. https://doi.org/10.28945/400

Cramer, K.M., Collins, K.R., Snider, D., \& Fawcett, G. (2007). The virtual lecture hall: Utilisation, effectiveness and student perceptions. British Journal of Education Technology, 38(1), 106-115. https://doi.org/10.1111/j.1467-8535.2006.00598.x

Chester, A., Buntine, A., Hammond, K., \& Atkinson, L. (2011). Podcasting in Educational: Student Attitudes, Behaviour and Self-Efficacy. Educational Technology \& Society, 14(2), 236-247.

Choi, H.J., \& Johnson, S.D. (2007). The effect of problem-based video instruction on learner satisfaction, comprehension and retention in college courses. British Journal of Educational Technology, 38, 885-895. https://doi.org/10.1111/j.1467-8535.2006.00676.x

Davenport, T.H., \& Beck, J.C. (2001). The attention economy: understanding the new currency of business. Boston, Massachusetts: Harvard Business School Press.

Dolnicar, S. (2005). Should We Still Lecture or Just Post Examination Questions on the Web? The nature of the shift towards pragmatism in undergraduate lecture attendance. Quality in Higher Education, 11(2), 103-115. https://doi.org/10.1080/13538320500175027

Dupuis, J., Coutu, J., \& Laneuville, O. (2013). Application of linear mixed-effect models for the analysis of exam scores: Online video associated with higher scores for undergraduate students with lower grades. Computers \& Education, 66, 64-73. https://doi.org/10.1016/j.compedu.2013.02.011

Ellis, T.J., \& Cohen, M.S. (2001). Integrating multimedia into a distance learning environment: Is the game worth the candle?. British Journal of Educational Technology, 32(4), 497-500.

https://doi.org/10.1111/1467-8535.00218 
Evans, C. (2008). The effectiveness of m-learning in the form of podcast revision lectures in higher education. Computers \& Education, 50(2), 491-498. https://doi.org/10.1016/j.compedu.2007.09.016

Fernández, F., \& Martínez Abadía, J. (2007). Manual básico de lenguaje y narrativa audiovisual. Barcelona: Ediciones Paidós Ibérica, S.A.

Fernández, M., Fernández, M.M., \& Ortiz, S. (2003). Las nuevas tecnologías en la enseñanza de “Organización y gestión de la producción”. Nuevas Tecnologías en la Innovación Educativa, (72).

Fernández, V., Simó, P., \& Sallán, J.Ma . (2009). Podcasting: A new technological tool to facilitate good practice in higher education. Computers \& Education, 53(2), 385-392.

https://doi.org/10.1016/j.compedu.2009.02.014

Fisher, M., \& Baird, D.E. (2006). Making mlearning work: Utilizing mobile technology for active exploration, collaboration, assessment, and reflection in higher education. Journal of Educational Technology Systems, 35(1), 3-30. https://doi.org/10.2190/4T10-RX04-113N-8858

Fjortoft, N. (2005). Students' motivation for class attendance. American Journal of Pharmaceutical Education, 69, 107-112. https://doi.org/10.5688/aj690115

Foertsch, J., Moses, G.A., Strikwerda, J.C., \& Litzkow, M.J. (2002). Revising the lecture/homework paradigm using eTechR web-based streaming video software. Journal of Engineering Education, 91(3), 267-274. https://doi.org/10.1002/j.2168-9830.2002.tb00703.x

Fourcade, A. (2008). Nuevas tecnologías aplicadas a la educación. Alicante: Universidad de Alicante.

Giannakos, M.N., \& Vlamos, P. (2013). Using webcasts in education: Evaluation of effectiveness. British Journal of Educational Technology, 44(2), 432-441. https://doi.org/10.1111/j.1467-8535.2012.01309.x

Goldhaber, M.H. (1997). The attention Economy and the Net. First Monday, 2(4). Available at: http://www.firstmonday.org/issues/issue2 4/goldhaber/ (Last access date: October, 2012).

Hallett, T.L, \& Faria, G. (2006). Teaching with multimedia: Do bells and whistles help students learn? Journal of Technology in Human Services, 24(2-3), 167-179. https://doi.org/10.1300/J017v24n02_10

Hampton, C. (2002). Teaching practical skills. In: A.K. Mishra \& J. Bartram (Editors), Perspectives on distance education: Skills development through distance education, commonwealth of learning. Vancouver: Commonwealth of Learning.

Hew, K.F. (2009). Use of audio podcast in K-12 and higher education: A review of research topics and methodologies. Education Technology Research and Development, 57(3), 333-357. 
Hill, J.L., \& Nelson, A. (2011). New technology, new pedagogy? Employing video podcasts in learning and teaching about exotic ecosystems. Environmental Education Research, 57(3), 393-408. https://doi.org/10.1080/13504622.2010.545873

Jarvis, C., \& Dickie, J. (2009). Acknowledging the "forgotten" and the unknown": The role of video podcasts for supporting field-based learning. Planet, 22, 61-63. https://doi.org/10.11120/plan.2009.00220061

Jung, I. (2005). Innovative and Good Practices of Open and Distance Learning in Asia and the Pacific Region. APEID, UNESCO. Bangkok Occasional Paper Series, Paper No. 3. Available at: http://unesdoc.unesco.org/images/0015/001529/152961e.pdf (Last access date: October, 2013).

Kay, R.H. (2012). Exploring the use of video podcasts in education: A comprehensive review of the literature. Computers in Human Behavior, 28(3), 820-831. https://doi.org/10.1016/j.chb.2012.01.011

Kay, R.H., \& Kletskin, I. (2012). Evaluating the use of problem-based video podcasts to teach mathematics in higher education. Computers \& Education, 59(2), 619-627. https://doi.org/10.1016/j.compedu.2012.03.007

Lazzari, M. (2009). Creative use of podcasting in higher education and its effect on competitive agency. Computers \& Education, 52(1), 27-34. https://doi.org/10.1016/j.compedu.2008.06.002

Lee, M.J.W., \& Chan, A. (2007). Reducing the effects of isolation and promoting inclusivity for distance learners through podcasting. Turkish Online Journal of Distance Education, 8(1), 85-104.

Lonn, S., \& Tesasley, S.D. (2009). Podcasting in higher education: What are the implications for teaching and learning?. Internet and Higher Education, 12, 88-92. https://doi.org/10.1016/j.iheduc.2009.06.002

McGarr, O. (2009). A review of podcasting in higher education: Its influence on the traditional lecture. Australasian Journal of Educational Technology, 25(3), 309-321. https://doi.org/10.14742/ajet.1136

McKinney, A., \& Page, K. (2009). Podcasts and video streaming: Useful tools to facilitate learning of pathophysiology in undergraduate nurse education?. Nurse Education in Practice, 9(6), 372-376. https://doi.org/10.1016/j.nepr.2008.11.003

McKinney, D., Dyck, J.L., \& Luber, E.S. (2008). iTunes University and the classroom: Can podcasts replace professors?. Computers \& Education, 52(3), 617-623. https://doi.org/10.1016/j.compedu.2008.11.004

Martínez R., \& García-Beltrán, J. (2003) Experiencia en el uso de las nuevas tecnologías en la Universidad Politécnica de Madrid. Jornada de Nuevas Tecnologías en la Innovación Educativa 2003 (41-48). 
Marx, R.D., \& Frost, P.J. (1998). Towards optimal use of video in management education: Examining the evidence. Journal of Management Development, 17(4), 243-250. https://doi.org/10.1108/02621719810210154

Nagy, J.T., \& Bernschütz, M. (2015). The impact of webinar-webcast system on learning performance. Educational Technology Research and Development, $\mathrm{n}^{\circ}, 1-9$.

Núñez, A. (2007). jSerá mejor que lo cuentes! Los relatos como herramientas de comunicación Storytelling. Barcelona: Ediciones Urano.

Peters, O. (1998). Learning and Teaching in Distance Education. London: Kogan Page Limited.

Pink, S. (2007). Doing visual ethnography. London: Sage Publications. https://doi.org/10.4135/9780857025029

Ractham, P., \& Zhang, X. (2006). Podcasting in Academia: A New Knowledge Management Paradigm within Academic Sttings. Actas del Congreso 2006 ACM SIGMIS CPR, Claremont, California (USA). Abril 13-15, 314-317. https://doi.org/10.1145/1125170.1125241

Rajadell, M., \& Garriga, F. (2013). Pasos para la elaboración de vídeos docentes en la formación universitaria. Libro de capitulos FECIES 2013. X Foro Internacional sobre la evaluación de la calidad de la investigación y de la educación superior (FECIES) (379-383). Asociación Española de Psicología Conductual (AEPC). Facultad de Psicología. Universidad de Granada.

Rea, P.W., \& Irving, D.K. (2002). Producción y dirección de cortometrajes y vídeos. Madrid: Instituto Oficial de Radio y Televisión. RTVE.

Robinson, K., \& Aronica, L. (2011). El Elemento. Descubrir tu pasión lo cambia todo. Barcelona: Debols!llo.

Rué, J. (2009). El Aprendiraje Autónomo en Educación Superior. Madrid: Narcea, S.A. de Ediciones.

Salinas, J. (2012). I uploadeda@Youtube video? ¿Una nueva perspectiva de la televisión educativa?. EDMETIC. Revista de Educación Mediática y TIC, 1(1), 8-28.

Salimpoor, V.N., Benevoy, M., Larcher, K., Dagher, A., \& Zatorre, R. (2011). Anatomically distinct dopamine release during abticipationj and experience of peak emotion to music. Nature Neuroscience, 14, 257-262. https://doi.org/10.1038/nn.2726

Shantikumar, S. (2010). From lecture theatre to portable media: Students' perceptions of an enhanced podcast for revision. Medical Teacher, 31(6), 535-538. https://doi.org/10.1080/01421590802365584

Shephard, K. (2003). Questioning, promoting and evaluating the use of streaming video to support student learning. British Journal of Educational Technology, 34(3), 295-538. https://doi.org/10.1111/14678535.00328 
Shyu, H.C. (2000). Using video based anchored instruction to enhance learning: Taiwan's experience. British Journal of Educational Technology, 31, 57-69. https://doi.org/10.1111/1467-8535.00135

Shrun, W., Duque, R., \& Brown, T. (2005). Digital video as research practice: Methodology for the millennium. Journal of Research Practice, 1(1), 1-19.

Simon, H.A. (1971). Designing organizations for an information-rich world. Baltimore: The Johns Hopkins Press.

Simó, J., et al. (2009). VideoStreaming: integració de vídeos docents de baix cost a ATENEA com a nova eina d'ensenyament-aprenentatge per a l'estudiantat d'enginyeria. 12è Premi a la Qualitat en la Docència Universitària. Consell Social Universitat Politècnica de Catalunya.

Steffens, K. (2001). Self-regulation and computer based learning. Anuario de la Facultad de Psicología de la Universitat de Barcelona, 32(2), 77-94.

Steffens, K. (2006). Self-Regulated learning in Technology-Enhanced Learning Environments: Lessons of a European peer review. European Journal of Education, 41(3-4), 353-379. https://doi.org/10.1111/j.1465-3435.2006.00271.x

Summers, G.F. (1982). Medición de actitudes. México: Editorial Trillas.

Traphagan, T., Kusera, J.V., \& Kishi, K. (2010). Impact of class lecture webcasting on attendance and learning. Educational Technology Research and Development, 58(1), 19-37. https://doi.org/10.1007/s11423-0099128-7

Weiers, R.M. (1986). Investigación de Mercados. Madrid: Prentice Hall.

Weinschenk, S.M., (2012). Presentaciones inteligentes. Madrid: Anaya Multimedia.

Wieling, M., \& Hofman, W. (2010). The impact of online lecture recordings and automated feedback on student performance. Computers \& Education, 54(4), 992-998. https://doi.org/10.1016/j.compedu.2009.10.002

Williams A., Birch, E., \& Hancock, P. (2012). The impact of online lecture recordings on student performance. Australasian Journal of Educational Technology, 28, 199-213. https://doi.org/10.14742/ajet.869

Wilson, E.O. (2007). La creación: Salvemos la vida en la tierra. Madrid: Katz Barpal Editores.

Wisher, R., \& Curnow, C.K. (1999). Perceptions and effects of image transmissions during internetbased training. American Journal of Distance Education, 13(3), 37-51. 
Winterbottom, S. (2007). Virtual lecturing: Delivering lectures using screen casting and podcasting technology. Planet, 18, 6-8. https://doi.org/10.11120/plan.2007.00180006

Zhang, D., Zhou, L., Briggs, R.O., \& Nunamaker, J.F. Jr. (2006). Instructional video in e-learning: Assessing the impact of interactive video on learning effectiveness. Information and Management, 43(1), 15-27. https://doi.org/10.1016/j.im.2005.01.004

Intangible Capital, 2017 (www.intangiblecapital.org)

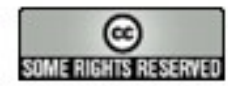

Article's contents are provided on an Attribution-Non Commercial 3.0 Creative commons license. Readers are allowed to copy, distribute and communicate article's contents, provided the author's and Intangible Capital's names are included. It must not be used for commercial purposes. To see the complete license contents, please visit http://creativecommons.org/licenses/by-nc/3.0/. 